\title{
Copulation and Oviposition in the Green-blotched Giant Anole, Anolis smallwoodi (Squamata: Dactyloidae), from southeastern Cuba
}

\author{
Yasel U. Alfonso $^{1}$, Veronika Holanova ${ }^{2}$ and Kenneth L. Krysko ${ }^{1}$ \\ ${ }^{1}$ Florida Museum of Natural History, Division of Herpetology, University of Florida, Gainesville, Florida 32611, USA (YUA: anoles1983cuba@gmail.com, \\ KLK: kenneyk@flmnh.ufl.edu) \\ ${ }^{2}$ Department of Zoology, Faculty of Science, Charles University in Prague, CZ-128 43 Praha 2, Czech Republic (igu@centrum.cz)
}

\begin{abstract}
Crown-giant anole ecomorphs have evolved independently across the Greater Antilles (Cuba, Hispaniola, Jamaica, and Puerto Rico), but only a few of these species have well documented life histories. Herein we report previously undocumented observations of copulation, oviposition, and hatchlings for the Green-blotched Giant Anole (Anolis smallwoodi) of southeastern Cuba. We observed eight mating events (three with A. s. smallwoodi and five with $A$. s. palardis) along the coastline between Santiago de Cuba and Guantánamo Province during June 2010 and September 2011. One female A. s. palardis mated with two males in the same territory. Females dig a hole with their snouts, oviposit single eggs, and cover them with substrate. We monitored eight eggs incubated in slightly moist vermiculite. The minimum incubation times were 54-69 days (varying with temperature). Juveniles usually are colored like adults, bright green with white spots on the body, pale postlabial bands, and suprascapular stripes.
\end{abstract}

Key words: crown-giant, copulation, oviposition, hatchling

Studies of Anolis lizards have indicated an important role for natural selection acting on morphology (Losos and de Queiroz 1997, Calsbeek and Smith 2007) and physiology (Calsbeek and Irschick 2007, Calsbeek et al. 2008). Differences in body size are thought to reflect differences in microhabitat use, and are important traits in the ecomorphological diversification of anoles (Butler and Losos 2002, Butler et al. 2007). Environmental factors such as temperature, photoperiod, precipitation, relative humidity, and food availability are important in the coordination of seasonal reproductive processes and also may help ensure that anoles will hatch at the most appropriate time of year to give them their best chance at survival (Domínguez et al. 2010).

Anolis lizards have low fecundity, with one egg per oviposition and several clutches per season (reviewed in Henderson and Powell 2009). However, of the 64 currently recognized species of Cuban anoles (Rodríguez-Schettino et al. 2013), the reproductive cycle is known for only seven (A. allisoni, A. allogus, A. homolechis, A. bartschi, A. lucius, A. porcatus, A. sagrei; see Domínguez et al. 2010 and references therein). Regarding oviposition, some authors have described intraspe- cific (Novo Rodríguez 1985, Estrada and Novo Rodríguez 1986; Silva et al. 1982; Estrada 1987, 1993; Robinson 2014) and interspecific (Alfonso et al. 2012) communal sites.

Crown-giant anole ecomorphs have evolved multiple times across the Greater Antilles (Cuba: Anolis baracoae, A. equestris, A. luteogularis, A. noblei, A. pigmaequestris, A. smallwoodi; Hispaniola: A. baleatus, A. barahonae, A. ricordii; Jamaica: A. garmani; and Puerto Rico: A. cuvieri, A. roosevelti; see Rodríguez-Schettino 1999, Henderson and Powell 2009, Losos 2009). Anolis smallwoodi Schwartz 1964 (Fig. 1A-C) has been found inhabiting both lowland and upland areas, semi-deciduous, evergreen, gallery, and rain forests, mangroves, and coffee plantations (Rodríguez-Schettino 1999, Henderson and Powell 2009). This species has large home ranges and multiple individuals are rarely observed together (Fläschendräger and Wijfels 1996, 2009); however, males and females can be observed together during the breeding season (VH, pers. obs.; Fig. 1D). Coloration in nature can vary individually and geographically (Rodríguez-Schettino 1999), and occasional deep-green individuals have blue spots on the dorsum (Fig. 1E). 

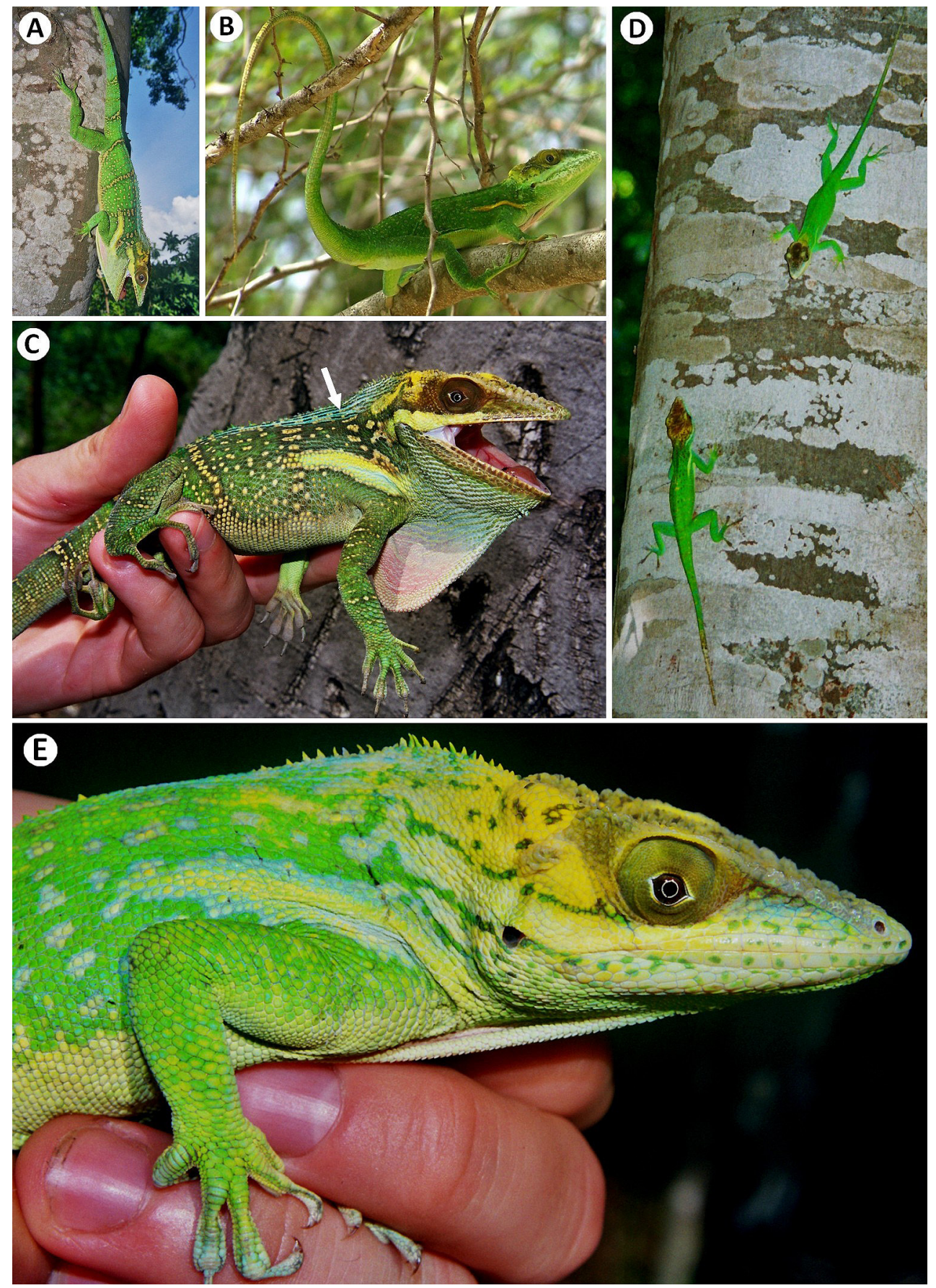

Fig. 1. Anolis smallwoodi smallwoodi on the southeastern coast of Cuba. A: Adult female perching face-down on a tree trunk. B: Adult male jumping on a branch of Dichrostachys cinerea. C: Adult female captured on a tree trunk, arrow indicate the blueness of the nuchal crest. D: paired couple during the breeding season. E: Adult female, note the strong yellow coloration on the head, blue coloration around the suprascapular stripe, and blue spots alternating with the bright green coloration on dorsum. Photographs from southeastern Santiago de Cuba province: Verraco (A, C-E) and Siboney-Jutici (B). Photographs by Veronika Holanova (A, C-E) and Yasel U. Alfonso (B).

Copulation time, oviposition, or hatching have been reported for some Greater Antillean crown-giant species (summarized in Henderson and Powell 2009). In this paper, our aim is to describe these natural history data for Anolis smallwoodi from semi-arid microhabitats in southeastern Cuba.

\section{Materials and Methods}

Study area and focal populations.-We conducted fieldwork from June 2010 to September 2011 at 1000-1500 h along the coastline between Santiago de Cuba and Guantánamo Provinces in southeastern Cuba. Dominant vegetation consisted of xerophytic scrub, microphyllous evergreen for- 
est, dry microphylous forest, and coastal hyperxeromorphic semidesert scrub (Capote and Berazaín 1984, Reyes 2006). We surveyed four localities for mating behavior (copulation) in Anolis smallwoodi (A. s. smallwoodi in Santiago de Cuba Province: Juraguá, $19.936805^{\circ} \mathrm{N}, 75.670188^{\circ} \mathrm{W}, 36$ $\mathrm{m}$ asl; Verraco, $19.907291^{\circ} \mathrm{N}, 75.575775^{\circ} \mathrm{W}, 23 \mathrm{~m}$ asl; $A$. s. palardis in Guantánamo Province: Baitiquirí, $20.030244^{\circ}$ $\mathrm{N}, 74.880822^{\circ} \mathrm{W}, 25 \mathrm{~m}$ asl; Yacabo Abajo, $20.052266^{\circ} \mathrm{N}$, $74.699741^{\circ} \mathrm{W}, 11 \mathrm{~m}$ asl).

In most instances, we observed copulation while using a monocular Nikon Fieldscope at distances of 13-37.4 m. We describe mating behavior involving three phases: precopulation, copulation, and postcopulation. We measured the duration of each stage with a digital chronometer $( \pm 0.1 \mathrm{~s})$. Means are presented \pm one standard deviation.

Ovipositioning behavior in captivity.-Captive individuals observed during oviposition belong to the private collection of Veronika Holanova in Prague, Czech Republic. Anoles were maintained in pairs inside terraria $(50 \times 50 \times 80 \mathrm{~cm})$ with approximately $5 \mathrm{~cm}$ of mixed lignocel and sand (proportion 2:1) as a substrate. Branches were placed vertically and horizontally inside terraria. Giant anoles prefer wide, vertical branches for daily activities and thin, horizontal branches for sleeping at night (VH, pers. obs.). Live plants (e.g., Ficus benjamina) from the leaves of which anoles lick water also were placed in terraria. The back wall of each terrarium was covered with cork bark.

Temperature was regulated with 40 -watt bulbs in ceramic shades. Light was provided with fluorescent tubes $(2 \times 25$ watt $)$ above the terraria. Daytime temperatures ranged between $26-28^{\circ} \mathrm{C}\left(35^{\circ} \mathrm{C}\right.$ directly under the bulb) and nighttime temperatures never dropped below $22^{\circ} \mathrm{C}$. Terraria were misted daily with water. Each oviposited egg was weighed (Ew) and measured (EL: egg length; EW: egg width). After hatching, neonates were measured (TL: total length, SVL: snout-ventlength, HL: head length) and weighed (NW: neonatal weight). Measurements were taken with a digital caliper (Mitutoyo CD-20DC, Sakato, Japan; precision, $\pm 0.01 \mathrm{~mm}$ ) and mass with a Kern $440-33 \mathrm{~N}$ electronic balance $( \pm 0.01 \mathrm{mg})$.

\section{Results}

Copulatory behavior.-We observed eight mating events, three involving A. s. smallwoodi and five A. s. palardis. During the May-to-September breeding season, most observations were of pairs (usually a single male and female on the same tree). Males copulated exclusively with those females located within their territories (YUA and VH, pers. obs.). Only one female A. smallwoodi palardis mated with multiple (two) males in the same territory (see details below).

Males initiated the precopulatory phase by closely following receptive females that usually submitted to a male's advances when he climbed onto her back. At that point, males made a sudden lateral movement and grasped the female, effectively rendering her immobile (Fig. 2A). The male's grip on the female's dorsum differs between the two subspecies; it is middorsal for A. s. smallwoodi (Fig. 2B) and more anterior for A. s. palardis (Fig. 2C). Subsequent preparation for penetration was expeditious, with male tail and hindlimb overlapping the female's tail (Fig. 2B-C). Precopulation took $7.11 \pm 3.78 \mathrm{~min}($ A. s. smallwoodi) and $5.47 \pm 3.5 \mathrm{~min}(A$. s. palardis). The male's grasp of the female was maintained throughout copulation.

The copulatory phase began when females responded to intromission by making an abrupt movement. Mating was similar between subspecies; neither moved the body, although females performed some slow lateral head swings. Copulatory duration was similar in both subspecies $(A$. s. smallwoodi: $44.2 \pm 23.5 \mathrm{~min}$; A. s. palardis: $40.6 \pm 20.1$ $\mathrm{min})$. The postcopulatory phase began with the separation that occurs without any sudden movements. Females initiated separation with elevation of their hindlimbs to facilitate extraction of the hemipenis. After separation, lizards invariably moved upward until one or both were concealed among the leaves.

We observed one case of multiple copulation of Anolis smallwoodi palardis involving a pair $223 \mathrm{~cm}$ high on a tree trunk. Mating behavior and duration were similar to others observed for this subspecies. However, after separation, the adult male, seemingly unaware of the presence of another adult male, moved higher into the canopy while the female remained in the same initial position without any male protection. A nearby male (ca. $420 \mathrm{~cm}$ away and $137 \mathrm{~cm}$ above the ground in a bush) opportunistically entered the first male's territory and successfully copulated with the female that apparently remained receptive. The period between separation after the first copulation and the beginning of the second copulation was $123 \mathrm{~min}$. Mating behavior for the second mating was similar to others observed for the subspecies, but durations were relatively short for both precopulation (2.5 $\mathrm{min}$ ) and copulation $(29.7 \mathrm{~min})$. After separation, the female climbed upward into the canopy and the second male jumped from the trunk to another tree.

Oviposition behavior in captivity.-Paired males and females (all Anolis smallwoodi smallwoodi) initiated courtship behavior in March. After a short "chase," copulation lasted 10-30 min. (Fig. 3A-B). Females ready to lay eggs descended from elevated perches to the substrate, where they dug a few "test" holes apparently searching for a site with optimal temperature and humidity. When satisfied with a location, a female digs a hole with her snout, lays an egg and rolls it in substrate material (Fig. 3C). When the egg is covered, she buries it using her snout and forelimbs before climbing onto an elevated perch. The entire process 

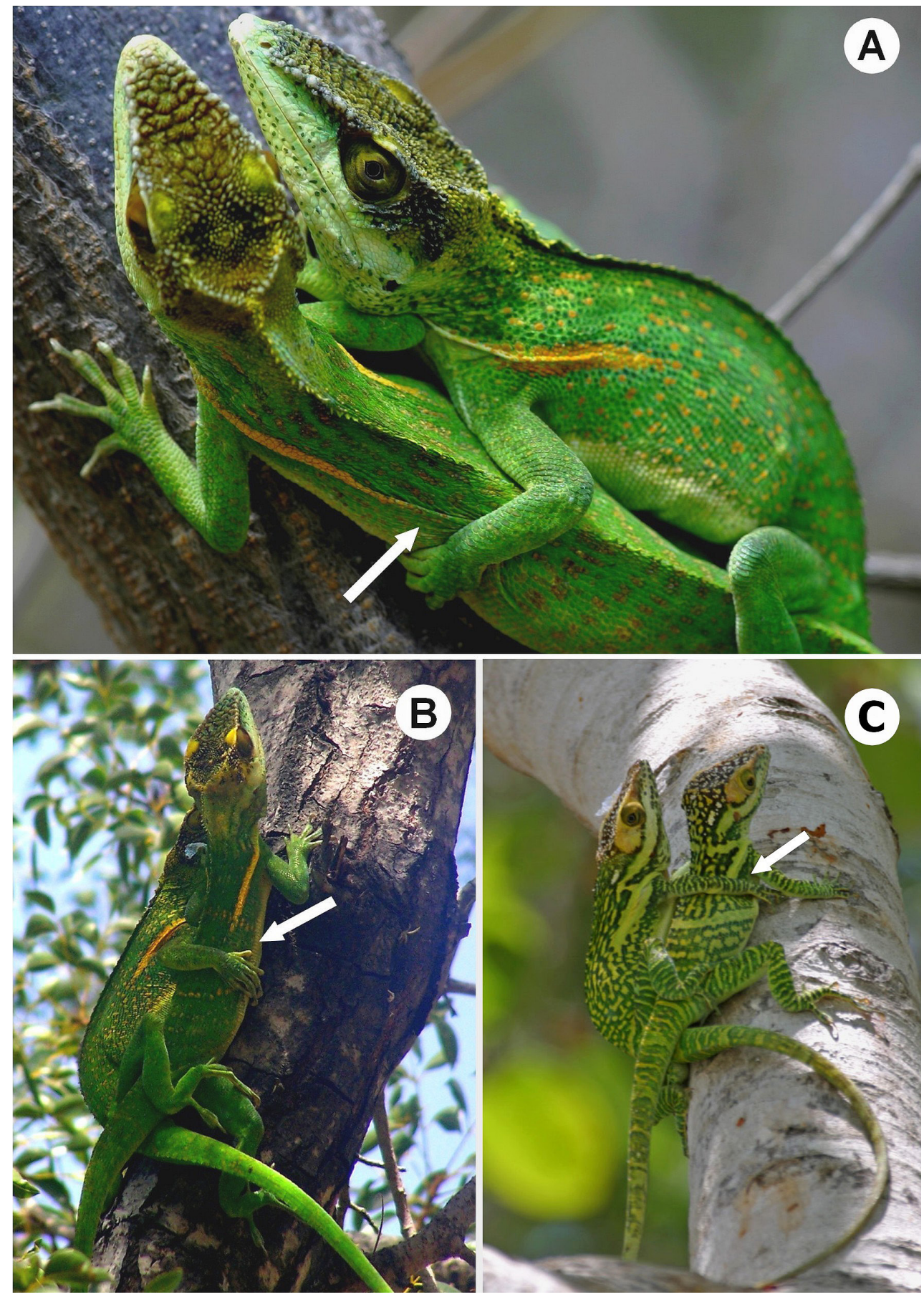

Fig. 2. Mating behavior in Anolis smallwoodi in southeastern Cuba. Arrows represent the male grasp position. A-B: A. smallwoodi smallwoodi and C: A. smallwoodi palardis. Photographs by Yasel U. Alfonso (A-B) and Joseph Burgess (C).

takes about $20 \mathrm{~min}$. Males usually copulate with females the same day she lays an egg. Females always lay a single egg (Fig. 3C). Measurements for eight eggs were $2.59 \pm 0.45 \mathrm{~g}$ and 2.54 $\pm 0.12 \mathrm{~cm}$ by $1.33 \pm 0.08 \mathrm{~cm}$. Well-fed females can lay an egg every seven days during the March-September breeding season.

Eggs were incubated in slightly moist vermiculite at temperatures of $27-29^{\circ} \mathrm{C}$. The minimum incubation time was 54-69 days (varying with temperature). Three eggs were infertile, but measurements for four hatched neonates were $2.6 \pm 0.11 \mathrm{~g}$ and $13.8 \pm 0.32 \mathrm{~cm}(\mathrm{SVL}=4.61 \pm 0.15$ $\mathrm{cm}, \mathrm{HL}=1.54 \pm 0.03 \mathrm{~cm}$ ). Juveniles usually are colored like adults, bright green with white spots on the body, pale postlabial bands, and suprascapular stripes. We began feeding neonates two days after hatching. They accepted a wide range 

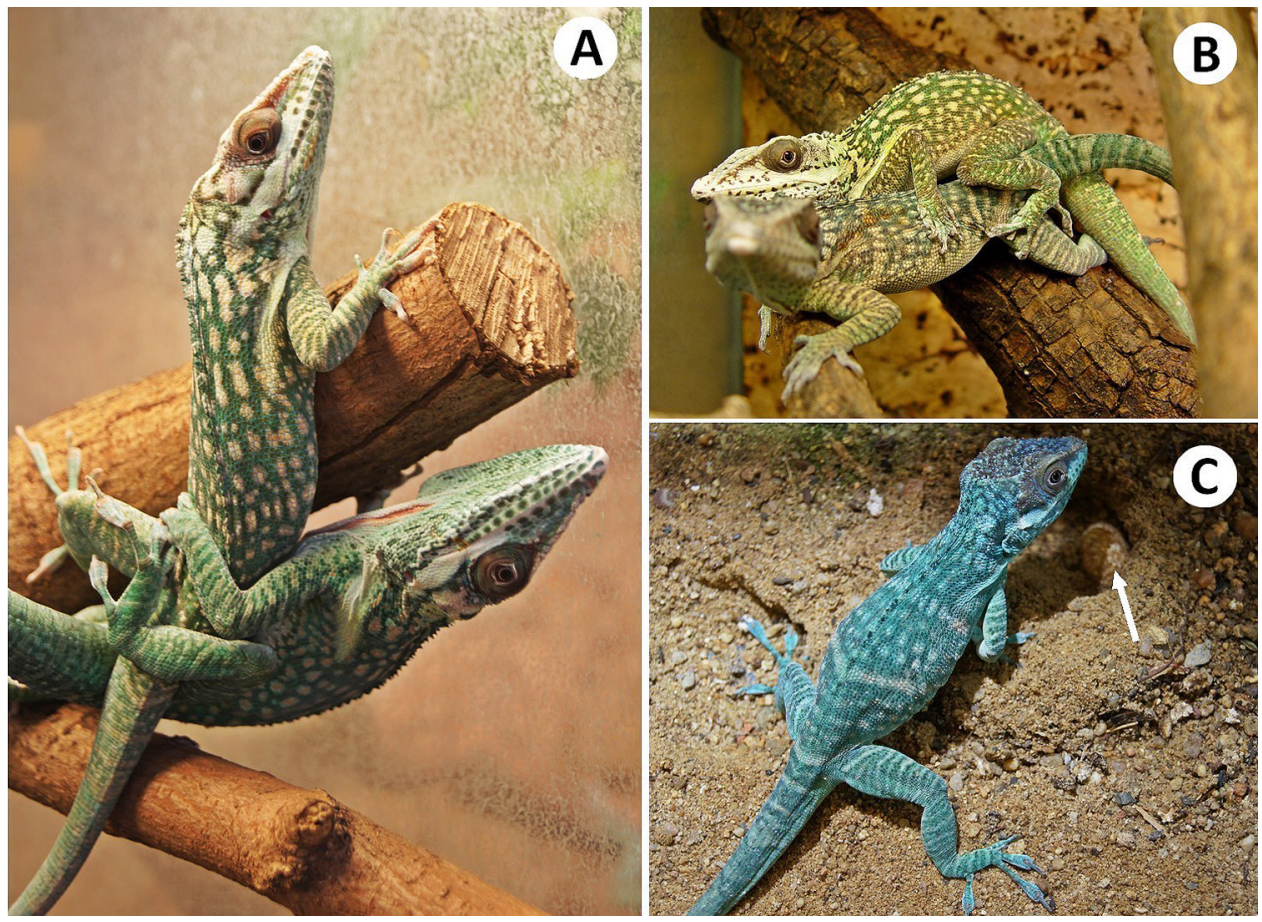

Fig. 3. A-B: Positions during mating in Anolis smallwoodi in captivity. C: Female burying a recently laid egg (arrow) using her forelimbs and snout. Note the blue coloration of this adult female. Photographs by Veronika Holanova.

of insects (e.g., crickets, grasshoppers, flies, and beetle larvae (Fig. 4C-D).

\section{Discussion}

Copulatory behavior.-Reproductive behavior is not well documented for Greater Antillean crown-giant anoles. Reviews by Rodríguez-Schettino (1999), Henderson and Powell (2009), and Losos (2009) included pertinent information for only some species (i.e., Anolis baleatus, A. baracoae, A. barahonae, A. cuvieri, A. equestris, A. garmani, and A. pigmaequestris). The mating behavior of three Cuban crown-giants for which we have some information (A. baracoae, A. luteogularis, and A. noblei) is similar in some aspects to that of $A$. smallwoodi. All have been observed in pairs (usually one male and one female on the same tree) and precopulation usually is initiated when a male follows a female from behind and ends with the male grasping and largely immobilizing the female (YUA, pers. obs.).

Our observations also suggest that Anolis smallwoodi exhibits behavior similar to that of other Greater Antillean crown-giants (Losos, 2009 and references therein). RiosLópez and Puente-Colón (2007) observed multiple sleeping pairs of $A$. cuvieri and suggested that this might be indicative of pair-bonding. Rodríguez-Schettino (1999) noted that courtship and mating in $A$. equestris and $A$. luteogularis occurred in tall trees, and that only one or two individuals of the latter occupy a single tree. Apparently, crown-giants have large home ranges and two individuals are rarely seen together (Fläschendräger and Wijfels 1996, 2009).

The duration of copulation varies considerably among some species of anoles (Jenssen 1996). It can be lengthy in many species and, in at least some species, duration seems to vary consistently among males (Crews 1973, Tokarz 1988) and appears to be greater later in the breeding season (Stamps 1975, Tokarz 1999). In Jamaican A. garmani, Trivers (1976) recorded an average duration of $25 \mathrm{~min}$. For other Greater Antillean anoles, mean duration varies from a few seconds to more than an hour (e.g., A. sagrei, $3.8 \mathrm{~min} ;$ A. bremeri, 64.9 min; A. valencienni, 2 min; A. websteri, \pm 1 sec; Regalado and Garrido 1993; Henderson and Powell 2009; Losos 2009 and references therein).

Male anoles (non-crown-giant species) usually mate with multiple females in their territories, and those males with larger territories (presumably supporting more females) suffered more paternity loss to extra-pair copulations (Losos 2009 and references therein). Our observation of multiple copulations in one female $A$. smallwoodi palardis might be an example of cryptic mate choice, wherein females mate multiple times over an extended period and subsequently select a specific male's sperm to fertilize the egg (Losos 2009). Female A. garmani position themselves in exposed places, perhaps rendering mating males highly visible to other nearby males or to solicit males so that the female may choose among them (Trivers 1976, Hicks and Trivers 1983). Extra-pair copu- 

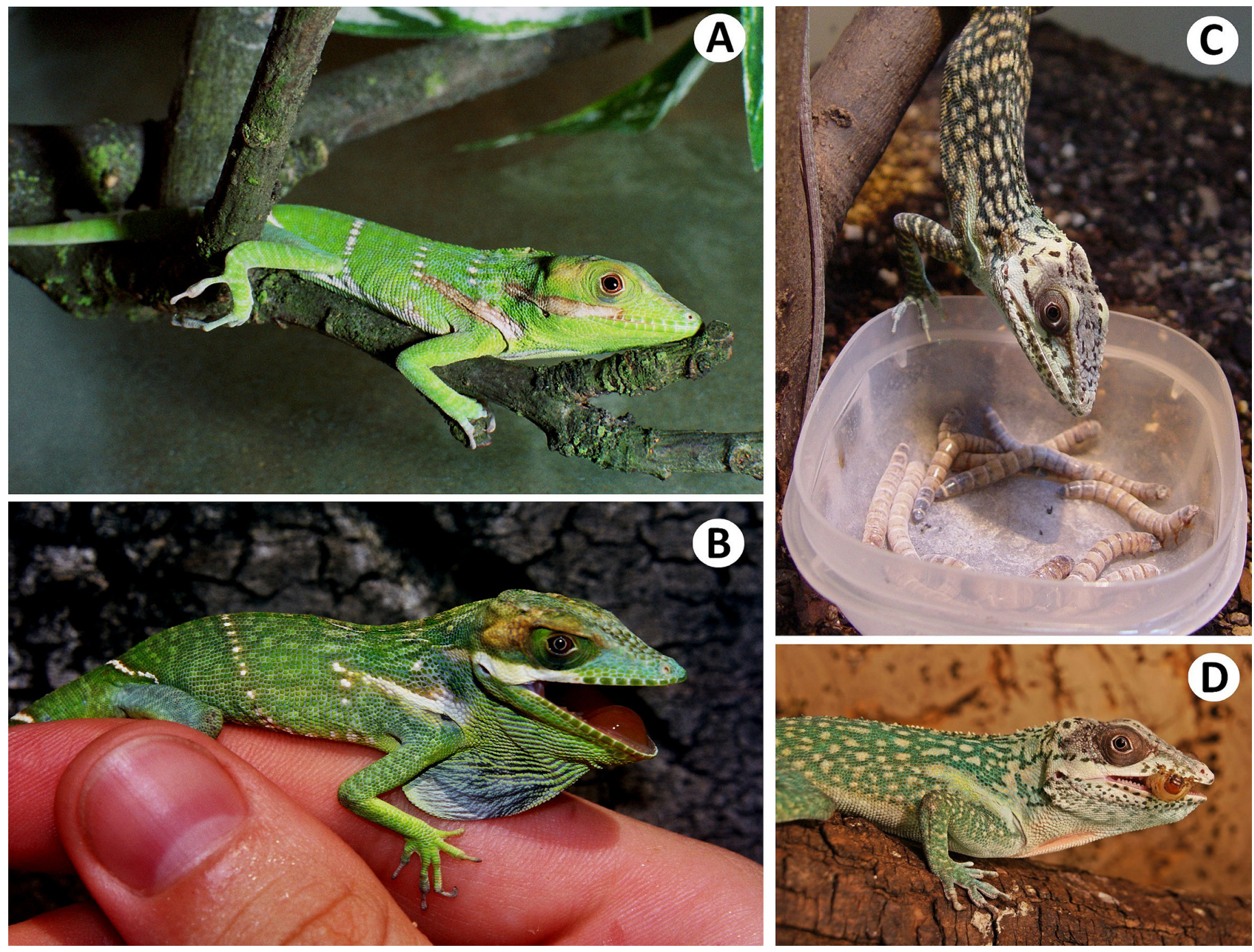

Fig. 4. A: Neonate Anolis smallwoodi smallwoodi. B: Holding a neonate outside the terrarium. C: Adult feeding on larvae of Zophobas morio (Tenebrionidae). D: Adult feeding on larvae of Pachnoda marginata (Scarabaeidae) inside the terrarium. Photographs by Veronika Holanova.

lations have been reported at least in one crown-giant species (A. garmani; Trivers 1976). Hicks and Trivers (1983) observed 49 copulation events in $A$. garmani, including both resident males and neighboring males (i.e., not with the main resident male within the territory).

Ovipositioning behavior in captivity.-Courtship behavior in captivity has been reported for some Greater Antillean crown-giants (Henderson and Powell 2009). Anolis baracoae can mate 2-3 times per week, and courtship involves headbobbing, dewlap extension, and paired couples facing down on vertical branches (Holanova and Hribal 2004). Appler (1963) recorded the duration of copulation for A. cuvieri in captivity; the range of 20-90 min is more variable than our observations of $A$. smallwoodi. Female anoles produce only one egg at a time with an average of 5-25 days between eggs (Andrews and Rand 1974, Andrews 1985). Only a single egg, usually from alternating ovaries, is ovulated at a time, but females can retain eggs during times of drought and thus sometimes carry as many as three eggs, two shelled and one in the oviduct (Stamps 1976).

Egg deposition reported herein for Anolis smallwoodi is similar to that described for other anoles. Females usually begin by selecting a potential site, probing the substrate with the snout, digging a hole into which an egg is deposited, and finally covering the egg with the substrate (Losos 2009 and references therein). For crown-giants, Rodríguez-Schettino (1999) observed a female $A$. equestris ovipositing in a hole near the base of a tree, and Panton (1928) described a female A. garmani descending a tree at midday, digging a small hole with her snout, and laying an egg.

Egg and hatchling sizes, incubation temperatures, and minimum incubation times have been reported for some crown-giants (Table 1). Incubation time for several Caribbean species can range from 3.5-6 weeks under laboratory conditions (Greenberg and Hake 1990, Sanger et al. 2008). Our 
Table 1. Mean oviposition data of crown-giant anoles in the Greater Antilles. MIT = minimum incubation time, IT = incubation temperature, SVL = snout-vent length. An asterisk indicates data obtained from our study. Neonate SVLs are given based on total length. Remaining data are from Losos (2009) and Henderson and Powell (2009), which should be consulted for the original sources in each case.

\begin{tabular}{lcccccc} 
Species & $\begin{array}{c}\text { Length } \\
(\mathbf{m m})\end{array}$ & $\begin{array}{c}\text { Eggs } \\
\text { Width } \\
(\mathbf{m m})\end{array}$ & $\begin{array}{c}\text { Mass } \\
(\mathbf{g})\end{array}$ & $\begin{array}{c}\text { MIT } \\
(\mathbf{d a y s})\end{array}$ & $\begin{array}{c}\text { IT } \\
(\mathbf{\circ})\end{array}$ & $\begin{array}{c}\text { Hatchling } \\
\text { SVL } \\
(\mathbf{m m})\end{array}$ \\
\hline Anolis smallwoodi & & & & \\
\hline Anolis baracoae & $23-27$ & $12-14$ & $1.7-3.1$ & $54-69$ & $27-29$ & $134-142$ \\
\hline Anolis cuvieri & $23-25$ & $6-7$ & - & $74-81$ & 26 & 130 \\
\hline Anolis equestris & $21-23$ & $11-12$ & - & 95 & $20-25$ & 41 \\
\hline Anolis garmani & $23-25$ & $12.8-18$ & - & $60-92$ & $18-30$ & $80-140$ \\
\hline Anolis pigmaequestris & $12-15$ & $8-11$ & - & $60-75$ & $24-26$ & 27 \\
\hline
\end{tabular}

results are generally similar to those previously reported for Caribbean species, although Bech (1986) observed one captive female $A$. equestris laying 12 eggs in one year (compared to one egg every seven days during breeding season in $A$. smallwoodi).

\section{Acknowledgements}

We thank Addael C. Casenave-Cambet (undergraduate student at University of Oriente) and Teresa Imbert (CATEDES/CITMA) for their assistance in the field. M.S. Javier Torres (University of Havana) and an anonymous reviewer provided helpful comments and suggestions on an earlier draft of this manuscript.

\section{Literature Cited}

Alfonso, Y.U., P. Charruau, G. Fajardo, and A.R. Estrada. 2012. Interspecific communal oviposition and reproduction of three lizard species in southeastern Cuba. Herpetology Notes 5:73-77.

Andrews, R.M. 1985. Oviposition frequency of Anolis carolinensis. Copeia 1985:259-262.

Andrews, R.M. and A.S. Rand. 1974. Reproductive effort in anoline lizards. Ecology 55:1317-1327.

Appler, H. 1963. Über Pflege und Zucht von Anolis cuvieri Merrem, dem Riesenanolis aus Portoriko. Die Aquarien- und Terrarienzeitschrift (DATZ) 16:279-282.

Bech, R. 1986. Zur Haltung und Vermehrung von Ritteranolis im Terrarium. Aquarien Terrarien 33:20-22.

Butler, M.A. and J.B. Losos. 2002. Multivariate sexual dimorphism, sexual selection, and adaptation in Greater Antillean Anolis lizards. Ecological Monographs 72:541-559.

Butler, M.A., S.A. Sawyer, and J.B. Losos. 2007. Sexual dimorphism and adaptive radiation in Anolis lizards. Nature 447:202-205.

Calsbeek, R. and D.J. Irschick. 2007. The quick and the dead: Correlational selection on morphology, performance, and habitat use in island lizards. Evolution 61:2493-2503.

Calsbeek, R. and T.B. Smith. 2007. Probing the adaptive landscape using experimental islands: Density-dependent natural selection on lizard body size. Evolution 61:1052-1061.

Calsbeek, R., C. Bonneaud, and T.B. Smith. 2008. Differential fitness effects of immunocompetence and neighbourhood density in alternative female lizard morphs. Journal of Animal Ecology 77:103-109.
Capote, R.P. and R. Berazaín. 1984. Clasificación de las formaciones vegetales de Cuba. Revista del Jardín Botánico Nacional de la Universidad de la Habana 5(2):27-75.

Crews, D. 1973. Coition-induced inhibition of sexual receptivity in female lizards (Anolis carolinensis). Physiology and Behavior 11:463-468.

Domínguez, M., A. Sanz, J. Chávez, and N. Almaguer. 2010. Cyclical reproduction in females of the Cuban lizard Anolis lucius (Polychrotidae). Herpetologica 66:443-450.

Estrada, A.R. 1987. Anolis argillaceus (Sauria: Iguanidae) un nuevo caso de puestas comunales en Anolis cubanos. Poeyana 353:1-9.

Estrada, A.R. 1993. Anfibios y reptiles de Cayo Coco, Archipiélago de SabanaCamagüey, Cuba. Poeyana 432:1-21.

Estrada, A.R. and J. Novo Rodriquez. 1986. Nuevos datos sobre las puestas comunales de Anolis bartschi (Sauria: Iguanidae) en la Sierra de los Organos, Pinas del Río, Cuba. Ciencias Biológicas 15:135-136.

Fläschendräger, A. and L.C.M. Wijfels. 1996. Anolis. Natur und Tier. Münster, Germany.

Fläschendräger, A. and L.C.M. Wijfels. 2009. Anolis. 2. vollständig überarbeitete und erweiterte Auflage. Natur und Tier. Münster, Germany.

Greenberg, N. and L. Hake. 1990. Hatching and neonatal behavior of the lizard, Anolis carolinensis. Journal of Herpetology 24:402-405.

Henderson, R.W. and R. Powell. 2009. Natural History of West Indian Reptiles and Amphibians. University Press of Florida, Gainesville.

Hicks, R.A. and R.L. Trivers. 1983. The social behavior of Anolis valencienni, pp. 570-595. In: A.G.J. Rhodin and K. Miyata (eds.), Advances in Herpetology and Evolutionary Biology: Essays in Honor of Ernest E. Williams. Museum of Comparative Zoology, Harvard University, Cambridge, Massachusetts.

Holanova, V. and J. Hribal. 2004. Anolis baracoae. Reptilia (Spain) 53:56-60.

Jenssen, T.A. 1996. A test of assortative mating between sibling lizard species, Anolis websteri and A. caudalis, in Haiti, pp. 303-315. In: R. Powell and R.W. Henderson (eds.), Contributions to West Indian Herpetology: A Tribute to Albert Schwartz. Contributions to Herpetology, volume 12. Society for the Study of Amphibians and Reptiles, Ithaca, New York.

Losos, J.B. 2009. Lizards in an Evolutionary Tree: Ecology and Adaptive Radiation of Anoles. University of California Press, Berkeley.

Losos, J.B. and K. de Queiroz. 1997. Evolutionary consequences of ecological release in Caribbean Anolis lizards. Biological Journal of the Linnaean Society 61:459-483.

Novo Rodríguez, J. 1985. Nido comunal de Anolis angusticeps (Sauria: Iguanidae) en Cayo Francés, Cuba. Miscelánea Zoológica 26:3-4.

Panton, E.S. 1928. Eight Months with the Green Lizard or the History of Anolis garmani. Times Printery, Kingston, Jamaica.

Regalado, R. and O.H. Garrido. 1993. Diferencias en el comportamiento social de dos especies gemelas de anolinos cubanos (Lacertilia: Iguanidae). Caribbean Journal of Science 29:18-23.

Reyes, J. 2006. Clasificación de la vegetación de la Región Oriental de Cuba. Biodiversidad de Cuba Oriental 8:28-42. 
Rios-López, N. and A.R. Puente-Colón. 2007. Anolis cuvieri (Puerto Rican Giant Anole). Reproduction. Herpetological Review 38:73-75.

Robinson, C.D., B.K. Kircher, and M.A. Johnson. 2014. Communal nesting in the Cuban Twig Anole (Anolis angusticeps) from South Bimini, Bahamas. Reptiles \& Amphibians 21:71-72.

Rodríguez-Schettino, L. 1999. The Iguanid Lizards of Cuba. University of Florida Press, Gainesville.

Rodríguez-Schettino, L., C.A. Mancina, and V. Rivalta González. 2013. Reptiles of Cuba: Checklist and geographic distributions. Smithsonian Herpetological Information Service 144:1-96.

Sanger, T.J., P.M. Hime, M.A. Johnson, J. Diani, and J.B. Losos. 2008. Laboratory protocols for husbandry and embryo collection of Anolis lizards. Herpetological Review 39:58-63.
Silva, A., V. Berovides, and A.R. Estrada. 1982. Sitios de puestas comunales de Anolis bartschi (Sauria: Iguanidae). Miscelánea Zoológica 15:1.

Stamps, J.A. 1975. Courtship patterns, estrus periods and reproductive conditions in a lizard, Anolis aeneus. Physiology and Behavior 14:531-535.

Stamps, J.A. 1976. Egg retention, rainfall and egg laying in a tropical lizard Anolis aeneus. Copeia 1976:759-764.

Tokarz, R.R. 1988. Copulatory behaviour of the lizard Anolis sagrei: Alternation of hemipenis use. Animal Behaviour 36:1518-1524.

Tokarz, R.R. 1999. Relationship between copulation duration and sperm transfer in the lizard Anolis sagrei. Herpetologica 55:234-241.

Trivers, R. 1976. Sexual selection and resource-accruing abilities in Anolis garmani. Evolution 30:253-269. 